\title{
PENERAPAN MODEL PROBLEM BASED LEARNING BERBANTUAN REINFORCEMENT SIMBOLIK UNTUK MENINGKATKAN MOTIVASI DAN HASIL BELAJAR MATEMATIKA SISWA KELAS IVB DI SD LAB UNDIKSHA
}

\author{
Ni Made Winursiti \\ 1) Jurusan Pendidikan Guru Sekolah Dasar. Universitas Pendidikan Ganesha
}

\begin{abstract}
Abstrak
Penelitian ini adalah penelitian tindakan kelas yang bertujuan untuk meningkatkan motivasi dan hasil belajar Matematika melalui penerapan model problem based learning berbantuan reinforcement simbolik. Penelitian ini tergolong penelitian tindakan kelas. Setiap siklus terdiri dari perencanaan, pelaksanaan, observasi atau evaluasi, dan refleksi. Subjek penelitian ini adalah siswa kelas IVB SD Lab Undiksha yang terdiri dari 19 orang siswa laki-laki dan 19 orang siswa perempuan. Bentuk analisis data yang digunakan adalah analisis data deskriptif kuantitatif. Data hasil penelitian menunjukan pada siklus I data hasil motivasi belajar siswa mencapai $68,60 \%$ berada pada katagori motivasi cukup tinggi dan pada siklus II mencapai $80,04 \%$ berada pada katagori motivasi tinggi. Dengan demikian, peningkatan motivasi belajar siswa mencapai $11,44 \%$. Sedangkan data hasil penelitian menunjukan pada siklus I data hasil belajar Matematika mencapai $68,95 \%$ berada pada katagori tinggi dan pada siklus II mencapai $81,18 \%$ berada pada katagori sangat tinggi. Dengan demikian, peningkatan hasil belajar Matematika mencapai 12,23\%. Hasil penelitian ini menunjukkan bahwa penerapan model problem based learning berbantuan reinforcement simbolik dapat meningkatkan motivasi dan hasil belajar Matematika siswa kelas IVB semester I tahun pelajaran 2017/ 2018 di SD Lab Undiksha.
\end{abstract}

\author{
Keywords: \\ problem based learning, \\ reinforcement simbolik, \\ motivasi belajar, dan \\ hasil belajar
}

\section{Pendahuluan}

Pendidikan nasional bertujuan untuk meningkatkan kehidupan bangsa dan mengembangkan manusia seutuhnya. Pendidikan diharapkan dapat meningkatkan kemampuan, mutu kehidupan serta dapat menghasilkan manusia terdidik (Yanti, 2013) . Menurut Santyasa (2006). Oleh karena itu, mutu pendidikan yang tinggi diperlukan untuk menciptakan sumber daya manusia yang cerdas dan profesional dalam era globalisasi ini sehingga dapat meningkatkan kesejahteraan. Pendidikan merupakan suatu rangkaian peristiwa yang kompleks, namun peranannya sangat penting bagi kehidupan manusia. Dengan pendidikan, manusia akan berusaha mengenal, mengembangkan dan memanfaatkan kemampuan yang dimilikinya (Siti 2016). Oleh sebab itu, pendidikan sangat diperlukan oleh manusia seumur hidupnya.

Pendidikan dicapai dengan melaksanakan pembelajaran. Pembelajaran merupakan suatu proses interaksi antara komponenkomponen sistem pembelajaran. Komponen-komponen pembelajaran adalah peserta didik, guru, kurikulum, tujuan pembelajaran, materi pembelajaran, fasilitas dan prosedur serta alat atau media yang harus dipersiapkan (Andriaswari, 2016). Salah satu mata pelajaran yaitu matematika. Matematika adalah pelajaran yang penting diajarkan di sekolah dasar. Hal ini karena Matematika mendasari ilmu-ilmu lain, membekali siswa berpikir kritis, serta dibutuhkan dalam kehidupan sehari-hari siswa untuk membantu memecahkan persoalan sehari-hari. Sekolah sebagai suatu lembaga pendidikan formal secara sistematis telah merencanakan bermacam lingkungan, yakni lingkungan pendidikan yang menyediakan bermacam kesempatan bagi siswa untuk melakukan berbagai kegiatan belajar sehingga para siswa memperoleh pengalaman pendidikan. Dengan demikian dapat mendorong pertumbuhan dan perkembangannya ke arah suatu tujuan yang dicita-citakan (Hamalik, 2003:79). 
Sekolah Dasar (SD) merupakan lembaga pendidikan dimana siswa umurnya berkisar antara 7 tahun sampai dengan 13 tahun. Menurut Piaget (dalam Heruman, 2012:1), mereka berada pada fase operasional konkrit. Kemampuan yang tampak pada fase ini adalah kemampuan dalam proses berpikir untuk mengoperasikan kaidah-kaidah logika, meskipun masih terikat dengan objek yang bersifat konkrit.

Pembelajaran Matematika di SD merupakan kegiatan guru secara terprogram dalam desain instruksional untuk membuat siswa belajar secara aktif yang menekankan pada penyediaan sumber belajar alat bantu berupa media, dan alat peraga yang dapat memperjelas apa yang akan disampaikan oleh guru (Sriyanto, 2007:26). Pembelajaran berarti kegiatan guru dalam merancang bahan pengajaran agar pembelajaran dapat berlangsung secara efektif, yakni siswa dapat belajar secara aktif dan bermakna. Dalam pembelajaran Matematika, guru harus memahami bahwa kemampuan setiap siswa berbeda-beda, serta tidak semua siswa menyenangi pelajaran Matematika.

Secara umum, tujuan diberikannya Matematika di SD adalah untuk membantu siswa mempersiapkan diri agar sanggup menghadapi perubahan keadaan di dalam kehidupan dan di dunia yang selalu berkembang, melalui latihan bertindak atas dasar pemikiran secara logis, rasional, dan kritis. Serta mempersiapkan siswa agar dapat menggunakan Matematika dalam kehidupan sehari-hari dan dalam mempelajari berbagai ilmu pengetahuan.

Berdasarkan pengamatan langsung dan wawancara yang dilaksanakan dengan guru kelas IVB Bapak I Wayan Aryanta di SD Lab Undiksha, ditemukan permasalahan terkait pembelajaran Matematika. Hasil pengamatan dan wawancara dengan guru kelas, menunjukkan belum optimalnya motivasi dan hasil belajar siswa terutama dalam pelajaran Matematika. KKM di SD Lab Undiksha pada pelajaran Matematika yaitu 60. Berdasarkan nilai ulangan harian terdapat 22 siswa dari 37 siswa yang tidak lulus KKM. Setelah penulis melakukan observasi di dalam kelas IVB, pembelajaran Matematika masih berorientasi pada teacher center. Sistem pengajaran yang demikian menyebabkan siswa kurang berpartisipasi aktif dalam mengikuti pembelajaran, sehingga siswa menunjukkan motivasi belajar Matematika yang belum optimal.

Pembelajaran dengan metode ceramah baik digunakan untuk siswa yang memiliki gaya belajar terbaiknya adalah mendengarkan, namun tidak semua siswa di kelas itu memiliki gaya belajar yang sama. Metode ceramah yang dilakuakan oleh guru membuat siswa pasif, hal ini akan mempengaruhi motivasi dan hasil belajar siswa. Rendahnya motivasi dan hasil belajar Matematika siswa dipengaruhi oleh banyak faktor, misalnya masalah klasik tentang penerapan model pembelajaran Matematika. Model pembelajaran sangatlah penting untuk siswa. Ada beberapa siswa yang mengaku kurang memahami soal Matematika yang dikerjakan. Bahkan tidak jarang ditemui siswa yang tidak dapat menggunakan keterampilan menyelesaikan soal apabila diberikan soal sedikit berbeda dari apa yang dipelajari atau dicontohkan. Hal ini menunjukkan bahwa siswa mengalami kesulitan dalam menyelesaikan masalah Matematika. Selain itu, rata-rata siswa berpikiran bahwa Matematika adalah pelajaran yang sulit dan membosankan. Jadi peran guru disini sangat penting sebagai fasilitator guna membangkitkan semangat siswa ketika mereka cenderung pasif mengikuti pembelajaran.

Dalam pembelajaran Matematika di sekolah dasar, khusunya kelas IVB semester I di SD Lab Undiksha terdapat materi pengukuran panjang, pengukuran berat, bangun segi banyak, dan keliling bangun datar. Untuk memperkenalkan materi tersebut kepada siswa, sebenarnya bukan materi yang terlalu sulit untuk diajarkan. Akan tetapi guru harus memperhatikan proses berpikir siswa dalam mengetahui pengukuran panjang, pengukuran berat, bangun segi banyak, dan keliling bangun datar. Guru juga harus memperhatikan kemampuan dasar siswa terkait materi tentang pengukuran, bangun segi banyak, dan keliling bangun datar.

Jika siswa difasilitasi untuk berpikir, maka hal tersebuat akan mendorong siswa untuk berpikir kreatif. Oleh karena hal itulah guru dituntut untuk lebih kreatif, inovatif dalam memilih model pembelajaran yang tepat dan dapat membangun motivasi siswa dalam pembelajaran Matematika. Secara otomatis jika model pembelajaran yang digunakan dapat membangkitkan motivasi siswa, maka akan berdampak positif bagi hasil belajar siswa.

Berdasarkan uraian di atas, khususnya dalam meningkatkan motivasi dan hasil belajar Matematika sangat tidak efektif apabila hanya menggunakan metode ceramah dalam melakukan suatu proses pembelajaran di kelas. Oleh karena itu, perlu dilakukan suatu pengembangan model pembelajaran untuk meningkatkan motivasi dan hasil belajar Matematika, sehingga siswa dapat terlibat secara penuh di dalam pembelajaran. Model pembelajaran yang digunakan untuk meningkatkan motivasi dan hasil belajar Matematika yaitu dengan menggunakan model problem based learning berbantuan reinforcement simbolik.

Peran guru pada model problem based learning berbantuan reinforcement simbolik yaitu sebagai pemberi masalah, memfasilitasi investigasi dan dialog, serta memberikan dukungan (motivasi) dalam pembelajaran. Selain itu, guru juga berperan dalam mengembangkan aspek kognitif siswa bukan sekedar sebagai pemberi informasi. Sedangkan siswa berperan aktif sebagai penyelesai masalah dan pembuat 
keputusan bukan sebagai pendengar pasif. Model problem based learning berbantuan reinforcement simbolik dinilai mempunyai banyak kelebihan dibanding dengan model pembelajaran konvensional. Peneliti juga melihat model problem based learning berbantuan reinforcement simbolik menitikberatkan pada proses meningkatkan motivasi dan hasil belajar siswa dalam pelajaran Matematika, sehingga model pembelajaran problem based learning berbantuan reinforcement simbolik dapat dijadikan sebagai salah satu solusi guru dalam mengatasi permasalahan yang terjadi pada siswa.

Atas dasar inilah peneliti membuat judul "Penerapan Model Problem Based Learning Berbantuan Reinforcement Simbolik Untuk Meningkatkan Motivasi dan Hasil Belajar Matematika Siswa Kelas IVB Semester I Tahun Pelajaran 2017 / 2018 di SD Lab Undiksha".

\section{Metode Penelitian}

Penelitian ini dilaksanakan pada kelas IVB semester I tahun pelajaran 2017/2018 di SD Lab. Undiksha dalam pelajaran Matematika. Penentuan waktu penelitian mengacu pada kalender pendidikan sekolah. Penelitian ini dilaksanakan dari bulan September sampai dengan bulan Oktober 2017. Subjek dalam penelitian ini adalah siswa kelas IVB semester I tahun pelajaran 2017/ 2018 di SD Lab. Undiksha. Berikut adalah tabel distribusi subjek penelitian.

Tabel 1. Tabel Distribusi Subjek Penelitian

\begin{tabular}{clrc}
\hline No. & & Aspek & Jumlah \\
\hline 1. & Laki-laki & & 18 \\
2. & Perempuan & & 20 \\
& & Jumlah & $\mathbf{3 8}$ \\
\hline
\end{tabular}

(Sumber: Wali Kelas IVB)

Penelitian ini mengacu pada teori yang dikemukakan Kemmis dan McTaggart (dalam Agung, 2014:91) yang masing-masing siklus terdiri dari empat tahap yaitu: (a) perencanaan tindakan; (b) pelaksanaan tindakan; (c) observasi atau evaluasi; dan (d) refleksi. Penelitian ini dilaksanakan dalam beberapa siklus secara berkelanjutan sampai kriteria ketuntasan tercapai. Tiap siklus terdiri dari empat tahapan yaitu: perencanaan tindakan, pelaksanaan tindakan, observasi atau evaluasi, dan refleksi.

Terdapat dua variabel terikat dalam penelitian ini, yaitu motivasi belajar dan hasil belajar Matematika setelah penerapan model problem based learning berbantuan reinforcement simbolik dalam pembelajaran. Motivasi belajar merupakan dorongan atau kekuatan yang berasal dari dalam maupun luar diri siswa yang menimbulkan kegiatan serta arah belajar untuk mencapai tujuan yang dikehendaki siswa. Dalam pembelajaran di sekolah dasar, indikator motivasi belajar yang dapat dikembangkan yaitu: (1) adanya hasrat dan keinginan berhasil; (2) adanya dorongan dan kebutuhan dalam belajar; (3) adanya harapan dan cita-cita masa depan; (4) adanya penghargaan dalam belajar; (5) adanya kegiatan yang menarik dalam belajar; dan (6) adanya lingkungan belajar yang kondusif. Oleh karena itu, untuk mengukur motivasi belajar digunakan metode kuesioner saat pembelajaran berlangsung. Instrumen yang digunakan untuk mengamati motivasi belajar berupa lembar kuesioner motivasi belajar yang ditunjukkan dalam pembelajaran. Data yang dihasilkan dengan menggunakan lembar kuesioner adalah data yang bersifat interval (skor).

Hasil belajar merupakan perubahan tingkah laku yang dialami oleh siswa dalam pembelajaran, mencakup ranah kognitif, afektif, dan psikomotor yang biasanya dinyatakan dalam bentuk angka, huruf atau kata-kata (baik, sedang, kurang, dan sebagainya). Hasil belajar Matematika yaitu perubahan tingkah laku yang dialami oleh siswa dalam pembelajaran Matematika. Dalam kaitannya dengan penelitian ini, hasil belajar Matematika yang dimaksud yaitu hasil belajar yang dicapai oleh siswa dalam aspek kognitif setelah penerapan model problem based learning berbantuan reinforcement simbolik. Data hasil belajar Matematika dapat dikumpulkan dengan metode tes tertulis setelah pembelajaran berlangsung. Instrumen yang digunakan berupa lembar/ perangkat tes Matematika. Data hasil belajar Matematika adalah data yang bersifat interval (skor).

Setelah data dalam penelitian ini terkumpul, maka selanjutnya dilakukan analisis data. Dalam menganalisis data digunakan metode analisis statistik deskriptif dan metode analisis deskriptif kuantitatif. Namun, dalam menganalisis data pada penelitian ini digunakan metode analisis deskriptif kuantitatif.

Dalam pengantar metodologi penelitian, Agung menyatakan bahwa "metode analisis deskriptif kuantitatif adalah suatu cara pengolahan data yang dilakukan dengan jalan menyusun secara sistematis 
dalam bentuk angka-angka dan atau persentase mengenai keadaan suatu objek yang diteliti sehingga diperoleh kesimpulan umum" (Agung, 2014).

Data hasil penelitian dianalisis untuk memperoleh tingkatan motivasi dan hasil belajar Matematika. Hasil ini diinterpretasi dan disimpulkan untuk digunakan dalam menjawab permasalahan yang telah dirumuskan. Untuk memperoleh motivasi dan hasil belajar Matematika secara klasikal, analisis ini didasarkan pada rata-rata kelas $\left({ }^{-} \mathrm{X}\right)$ dari skor motivasi dan hasil belajar Matematika, mean ideal (MI) dan Standar deviasi (SDi). Adapun pedomannya yaitu sebagai berikut.

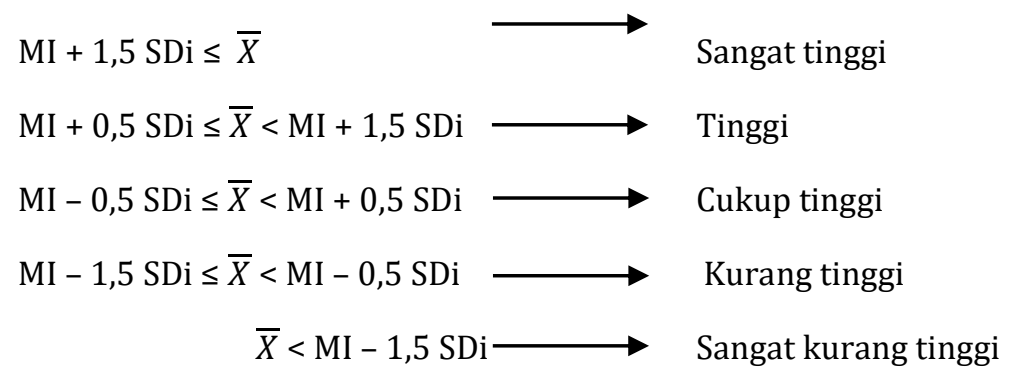

(Nurkancana dan Sunartana, 1992)

Indikator keberhasilan dari penelitian ini jika ditinjau dari motivasi dan hasil belajar Matematika setelah diterapkannya model problem based learning berbantuan reinforcement simbolik dalam pembelajaran, motivasi dan hasil belajar Matematika cenderung meningkat ke kategori tinggi atau sangat tinggi. Apabila indikator keberhasilan penelitian sudah tercapai, maka penelitian dapat dihentikan dan dibuat suatu simpulan dari hasil penelitian yang telah dilakukan

\section{Hasil Dan Pembahasan}

Penelitan ini dilaksanakan di SD Lab Undiksha pada siswa kelas IVB semester I tahun pelajaran 2017/2018, banyak siswa kelas IVB adalah 38 orang yang terdiri dari 19 siswa perempuan dan 19 siswa laki-laki. Pada penelitian ini yang diukur adalah motivasi dan hasil belajar Matematika melalui penerapan model problem based learning berbantuan reinforcement simbolik. Penelitian ini dirancang melalui beberapa siklus hingga menemukan tindakan yang terbaik. Pada siklus I terdiri dari perencanaan, pelaksanaan, observasi atau evaluasi dan refleksi siklus I. Apabila belum berhasil akan dilanjutkan ke siklus II yang terdiri dari perencanaan, pelaksanaan, observasi atau evaluasi dan refleksi siklus II. Apabila berhasil maka penelitian akan dihentikan karena telah mencapai target yang ditentukan.

Hasil penelitian menunjukkan motivasi belajar pada siklus I belum mencapai kriteria keberhasilan yaitu masih ada beberapa siswa secara individu memiliki motivasi belajar pada kategori kurang tinggi. Sedangkan hasil penelitian mengenai hasil belajar Matematika pada siklus I juga belum mencapai kriteria keberhasilan yaitu masih ada satu siswa secara individu memiliki hasil belajar Matematika pada kategori kurang tinggi dan beberapa siswa memiliki hasil belajar Matematika yang cukup tinggi. Hal ini disebabkan karena siswa kurang bersemangat saat pembelajaran berlangsung, sehingga motivasi dan hasil belajar Matematika belum mencapai kriteria keberhasilan yang ditentukan dalam penelitian ini. Maka dari itu segala upaya dirancang untuk menanggulangi kelemahan pada siklus I dan selanjutnya akan dilaksanakan pada siklus II. Pada siklus II, segala yang dirancang dan diupayakan berjalan dengan lancar sehingga pada siklus II terjadi peningkatan motivasi dan hasil belajar Matematika.

Berdasarkan analisis siklus I yaitu persentase motivasi belajar mencapai $68,60 \%$ berada pada kategori motivasi cukup tinggi, namun masih ada beberapa siswa yang berada pada kategori motivasi kurang tinggi. Sedangkan pada siklus II mencapai $80,04 \%$ berada pada kategori motivasi belajar tinggi, selain itu seluruh siswa sudah berada pada kategori motivasi belajar tinggi dan sangat tinggi. Kemudian, hasil analisis siklus I yaitu persentase hasil belajar Matematika mencapai 68,95\% berada pada kategori tinggi, namun masih ada satu siswa yang berada pada kategori kurang tinggi dan beberapa siswa berada pada kategori cukup tinggi. Sedangkan pada siklus II mencapai 81,18\% berada pada kategori hasil belajar Matematika sangat tinggi, selain itu seluruh siswa sudah berada pada kategori hasil belajar Matematika tinggi dan sangat tinggi.

Hal ini menunjukkan terjadi peningkatan pada motivasi belajar sebesar $11,44 \%$ dari siklus I ke siklus II dan terjadi peningkatan motivasi belajar secara individu maupun secara rata-rata klasikal secara keseluruhan. Selanjutnya, pada hasil belajar Matematika menunjukkan terjadi peningkatan sebesar $12,23 \%$ dari siklus I ke siklus II dan terjadi peningkatan hasil belajar Matematika secara individu maupun 
secara rata-rata klasikal secara keseluruhan. Secara umum penelitian ini dapat dikatakan berhasil, karena semua kriteria yang ditetapkan telah terpenuhi. Jadi, dapat dinyatakan bahwa penerapan model problem based learning berbantuan reinforcement simbolik dapat meningkatkan motivasi dan hasil belajar Matematika siswa kelas IVB semester I tahun pelajaran 2017/2018 di SD Lab Undiksha.

Penelitian ini di dukung oleh penelitian Gunantara (2014), yang menunjukan bahwa model pembelajaran Problem Based Learning (PBL) dapat meningkatkan kemampuan pemecahan masalah pada mata pelajaran Matematika. Sejalan dengan penelitian oleh Anggara (2013) yang menunjukkan bahwa penerapan model pembelajaran problem-based learning dapat meningkatkan aktivitas dan hasil belajar PKn siswa kelas XI IPA 4 SMA Negeri 1 Negara. Adapun kendala yang dihadapi dalam pembelajaran terutama adalah keterbatasan waktu belajar tatap muka. Selain itu penelitian oleh Putera (2012) menunjukkan hasil temuan penelitian, bahwa implementasi problem based learning berpengaruh terhadap hasil belajar Biologi ditinjau dari IQ pada siswa kelas XI IPA SMA Negeri 1 Ubud

\section{Simpulan dan Saran}

Berdasarkan hasil penelitian dan pembahasan yang telah diuraikan, dapat disimpulkan bahwa penerapan model problem based learning berbantuan reinforcement simbolik dapat meningkatkan motivasi dan hasil belajar Matematika siswa kelas IVB semester I tahun pelajaran 2017/2018 di SD Lab Undiksha.

Hal ini dapat dilihat dari meningkatnya motivasi belajar siswa pada siklus I yaitu persentase motivasi belajar mencapai $68,60 \%$ berada pada kategori motivasi cukup tinggi, namun masih ada beberapa siswa yang berada pada kategori motivasi kurang tinggi. Sedangkan pada siklus II mencapai $80,04 \%$ berada pada kategori motivasi belajar tinggi, selain itu seluruh siswa sudah berada pada kategori motivasi belajar tinggi dan sangat tinggi.

Hasil analisis siklus I yaitu persentase hasil belajar Matematika mencapai $68,95 \%$ berada pada kategori tinggi, namun masih ada satu siswa yang berada pada kategori kurang tinggi dan beberapa siswa berada pada kategori cukup tinggi. Sedangkan pada siklus II mencapai $81,18 \%$ berada pada kategori hasil belajar Matematika sangat tinggi, selain itu seluruh siswa sudah berada pada kategori hasil belajar Matematika tinggi dan sangat tinggi.

Hal ini menunjukkan terjadi peningkatan pada motivasi belajar sebesar $11,44 \%$ dari siklus I ke siklus II dan terjadi peningkatan motivasi belajar secara individu maupun secara rata-rata klasikal secara keseluruhan. Selanjutnya pada hasil belajar Matematika menunjukkan terjadi peningkatan sebesar $12,23 \%$ dari siklus I ke siklus II dan terjadi peningkatan hasil belajar Matematika secara individu maupun secara rata-rata klasikal secara keseluruhan.

\section{Daftar Pustaka}

Andriaswari, I Gst. A., Oka Negara, Wyn Wiarta. 2016. Penerapan Model Problem Based Learning (PBL) Berbantuan Media Konkret Dapat Meningkatkan Penguasaan Kompetensi Pengetahuan Matematika Siswa Kelas Vb Sd Negeri 10 Pemecutan. e-Journal PGSD Universitas Pendidikan Ganesha Jurusan PGSD Vol: 4 No: 1.

Anggara, I Gede. 2013. Penerapan Model Pembelajaran Problem-Based Learning Untuk Meningkatkan Aktivitas Dan Hasil Belajar Siswa Pada Mata Pelajaran Pkn. Jurnal Pendidikan Kewarganegaraan Universitas Pendidikan Ganesha Vol 1 No 4.

Gunantara, Gd. Md Suarjana, Pt. Nanci Riastini. 2014. Penerapan Model Pembelajaran Problem Based Learning Untuk Meningkatkan Kemampuan Pemecahan Masalah Matematika Siswa Kelas V. Jurnal Mimbar PGSD Universitas Pendidikan Ganesha Jurusan PGSD Vol: 2 No: 1.

Hamalik, Oemar. 2003. Belajar dan Pembelajaran. Jakarta: Rineka Cipta.

Heruman, 2012.Model Pembelajaran Matematika. Bandung: Remaja Rosda Karya.

Sriyanto. 2007. Strategi Sukses Menguasai Matematika. Yogyakarta: Indonesia Cerdas Strauss.

Agung, A. A. Gede. 2014. Metodologi Penelitian Pendidikan. Singaraja: FIP Undiksha.

Nurkhotimah, Siti, Joharman, dan Suripto. 2017. Penerapan Model Problem Based Learning (Pbl) Dengan Media Konkret Untuk Meningkatkan Hasil Belajar Matematika Tentang Operasi Hitung Pecahan 
Pada Siswa Kelas V Sdn 1 Kuwayuhan Tahun Ajaran 2016/2017. E-Journal Universitas Sebelas Maret Surakarta, tersedia Sunartana. 1992. Evaluasi Hasil Belajar. Surabaya: Usaha Nasional.

Putera, Ida Bgs Nym Semara. 2012. Implementasi Problem Based Learning (Pbl) Terhadap Hasil Belajar Biologi Ditinjau Dari Intelligence Quotient (IQ) . Jurnal Penelitian Pascasarjana Universitas Pendidikan Ganesha Vol 2 Nomor 2.

Yanti, Ni Wayan Widya, Sukadi, dan I Gusti Ketut Arya Sunu. 2013. Penerapan Model Pembelajaran PBL Berbantuan Power Point Untuk Meningkatkan Hasil Belajar PKN. E-Journal Universitas Pendidikan Ganesha, tersedia pada. https://ejournal.undiksha.ac.id/index.php/JPP/article/download/404/34. 